\title{
Laboratory-confirmed case of Middle East respiratory syndrome coronavirus (MERS-CoV) infection in Malaysia: preparedness and response, April 2014
}

J Premila Devi (premilausm@yahoo.com) ${ }^{1}$, W Noraini ${ }^{1}$, R Norhayati $^{1}$, C Chee Kheong $^{1}$, A S Badrul ${ }^{1}$, S Zainah $^{1}$, K Fadzilah $^{1}$, I Hirman ${ }^{1}$, S Lokman Hakim¹, A Noor Hisham ${ }^{1}$

1. Ministry of Health Malaysia

Citation style for this article:

Premila Devi J, Noraini W, Norhayati R, Chee Kheong C, Badrul AS, Zainah S, Fadzilah K, Hirman I, Lokman Hakim S, Noor Hisham A. Laboratory-confirmed case of Middle East respiratory syndrome coronavirus (MERS-CoV) infection in Malaysia: preparedness and response, April 2014. Euro Surveill. 2014;19(18): pii=20797.

Available online: http://www.eurosurveillance.org/ViewArticle.aspx?Articleld=20797

Article submitted on 25 April 2014 / published on 08 May 2014

On 14 April 2014, the first laboratory-confirmed case of Middle East respiratory syndrome coronavirus (MERS(oV) infection was reported in Malaysia in a man in his mid-fifties, who developed pneumonia with respiratory distress, after returning from a pilgrimage to Saudi Arabia. The case succumbed to his illness three days after admission at a local hospital. The follow-up of 199 close contacts identified through contact tracing and vigilant surveillance did not result in detecting any other confirmed cases of MERS-CoV infection.

Here we report a laboratory-confirmed case of Middle East respiratory syndrome (MERS-CoV) in a patient returning to Malaysia from an Umrah pilgrimage in Saudi Arabia.

\section{Case report and travel history}

\section{Case report}

On 9 April 2014, a man aged in his mid-fifties, on treatment for diabetes, presented at the emergency department of a public hospital in Malaysia with complaints of cough, fever and shortness of breath. Clinical investigation showed the patient to be afebrile with a temperature of $36.7^{\circ} \mathrm{C}$ and radiographic evidence of pneumonia. The next day, the patient was hospitalised, and because he had been travelling to Saudi Arabia 13 days prior, he was managed in an isolation room for suspected possible MERS-CoV infection. The staff of the local hospital and caring for the patient complied with infection prevention and control procedures according to national guidelines [1]. The patient was treated for a provisional diagnosis of communityacquired pneumonia. As bacteriological (culture of blood samples) investigation yielded negative results, the patient was treated with oseltamivir. On 10 April 2014, due to worsening of his condition he was intubated. However, the patient developed consecutive multi-organ failure and his condition further deteriorated. On 13 April 2014, throat samples were taken and he passed away on the same day.

\section{Laboratory investigation}

Diagnosis of MERS-CoV was confirmed by polymerase chain reaction (PCR) in the hospital laboratory on 14 April 2014. A real-time reverse-transcription PCR (rRT-PCR) screening assay targeting upstream of the envelope gene (upE assay) and a rRT-PCR confirmatory assay targeting the open reading frame (ORF) 1a yielded positive results. On 15 April 2014 sample was sent to the Institute for Medical Research (IMR), Kuala Lumpur, for sequencing of genes that code for the nucleocapsid (N) and RNA-dependent RNA polymerase (RdRp) proteins of the MERS-CoV [2].

\section{Travel history}

The travel history of the case was obtained from interviewing a relative who travelled with him. The interview was carried out using the standard questionnaire recommended by the World Health Organization (WHO) [3]. The case travelled to Saudi Arabia from 15 to 28 March 2014 to perform the Umrah pilgrimage with a group of 17 fellow pilgrims. Following the Umrah rituals on 26 March, he visited a camel farm in Saudi Arabia, where he patted camels and consumed unpasteurised camel milk sold by vendors at the farm. On 28 March, the case and his travel group boarded a flight from Jeddah, Saudi Arabia, to Istanbul, Turkey, and took another connecting flight from Istanbul to Malaysia where they arrived on 29 March 2014. The case was well during his travel and went back to his village on same day of arrival. The patient started feeling unwell on 4 April 2014, and sought treatment in a private clinic on 7 April 2014. At the private clinic he complained of body aches and was given analgesics. A brief timeline of the case's travel, possible exposure to the virus, healthcare contacts and diagnosis is detailed in the Figure.

\section{Background on Middle East respiratory syndrome coronavirus}

Coronaviruses are enveloped RNA viruses classified in alpha, beta and gamma genera that can be found globally in birds, humans and other mammals [4]. MERS-CoV 


\section{FIGURE}

Timeline of possible exposure to Middle East respiratory syndrome coronavirus (MERS-CoV), travel, healthcare contacts and diagnosis of a case of MERS-CoV, Malaysia, March-April 2014

Activity and possible exposure to MERS-CoV during travel

\section{Night flight to Istanbul, Turkey \\ Visited tourist spots in Istanbul, Turkey \\ Left Istanbul and arrived at Medina, Saudi Arabia \\ Visited mosque in Medina, Saudi Arabia \\ Visited dates market, mosques and historical places in \\ Medina, Saudi Arabia}

Left Medina and arrived in Mecca, Saudi Arabia
Day

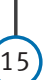

(15)
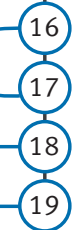

20

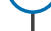

Activity after returning back to Malaysia

\section{\begin{tabular}{|l|}
\hline Performed Umrah rituals \\
performed Umrah rituals and visited a camel farm, \\
patted animals and drank unpasteurised camel milk \\
\hline $\begin{array}{l}\text { Performed Umrah rituals and travelled back to } \\
\text { home country: Jeddah-Istanbul-Kuala Lumpur }\end{array}$
\end{tabular}}


is a novel virus among the genus betacoronavirus [5]. The first case was identified in Saudi Arabia in June 2012, followed by another case from Qatar that was treated in the United Kingdom. Subsequently, a hospital cluster of pneumonia among healthcare workers in Jordan was traced retrospectively to this virus $[5,6]$. As of 24 April 2014, 254 laboratory-confirmed cases of MERS-CoV including 93 deaths, involving 12 countries, have been notified to the WHO [7].

Most MERS-CoV cases have been reported from Saudi Arabia, a country that hosts two important Muslim pilgrimages, the Hajj and the Umrah.The Hajj occurs during the month of Dhulhijjah that is the twelfth month of the Islamic Hijri calendar year. Any adult Muslim of a sane mind, able body and with means to bear the expenses must perform Hajj once in his/her lifetime. Hajj is not obligatory for children, the sick, and those who cannot bear the costs. The Umrah pilgrimage is a non-mandatory lesser pilgrimage made by Muslims to Mecca, which may be performed at any time of the year.

Ministry of Health, Malaysia: preparedness and response for Middle East respiratory syndrome coronavirus

Due to the large number of visitors to Saudi Arabia from Muslim countries around the world, in the context of the Hajj and the Umrah, such countries are potentially at risk for MERS-CoV importation. Malaysia contributes approximately 22,000 to 23,000 pilgrims annually to the Hajj and this figure may vary according to the quota given by the Saudi Arabian government. Bumiputera Travel and Tour Agents Association of Malaysia (BUMITRA) reported that Malaysia also has an annual average of 200,000 Umrah pilgrims.

The Ministry of Health $(\mathrm{MoH})$ in Malaysia works closely with BUMITRA for the Umrah pilgrims. Tour agencies organise a pre-departure talk for Umrah pilgrims including information on MERS-CoV, advice for preparation before the pilgrimage, in particular prevention and control measures to be taken during and after the pilgrimage. For Hajj pilgrims, MoH works with the Hajj Pilgrimage Fund Board, a government agency dedicated to providing lectures, medical examinations and vaccines to the Hajj pilgrims. During the Hajj period, medical teams are sent to Saudi Arabia and will remain there for the entire Hajj period to take care of the medical needs of Malaysia's Hajj pilgrims. In 2013, the medical teams consisted of a total of 250 medical personnel and these were coordinated by $\mathrm{MoH}$ through the Hajj Pilgrimage Fund Board.

Since 2013, MoH has distributed health alert cards to travellers including pilgrims and flight crews returning from Middle East countries. Those with mild respiratory symptoms are also given a home assessment tool, consisting of information such as sign and symptoms of MERS-CoV infection, when to seek medical care and simple steps on how to avoid transmission of illness to others.

In Malaysia, any person who presents with fever (defined as body temperature $\geq 38^{\circ} \mathrm{C}$ ), cough and breathing difficulty and has travelled or returned from Middle East countries within the past 14 days before symptom onset is advised to seek immediate care from the nearest healthcare facilities. In these facilities persons are clinically screened and if they fulfil the criteria for patient under investigation (PUI) for MERS-CoV as defined by WHO [8], they are referred to a hospital for further investigation. At the hospital, these patients receive treatment and samples are taken in order to test for MERS-CoV infection.

Guidance for management of PUI, probable and confirmed MERS-COV cases as defined by WHO [8] has been disseminated to all the Malaysian healthcare community, including private practitioners [9]. The guidance emphasised the importance of strict infection prevention and control measures among healthcare workers and continuously monitoring their implementation. Simulation exercises were conducted to test: (i) the preparedness to detect PUI MERS-CoV cases and further management; (ii) laboratory capacities and capabilities; (iii) infection control procedures at all levels; and (iv) risk communication of various $\mathrm{MoH}$ facilities.

Additional means to detect cases of MERS-CoV infection are the surveillance systems for respiratory infections already in place, such as the Malaysia Influenza Surveillance System (MISS) operating since September 2003 [10]. The surveillance of influenza-like illness (ILI) and severe acute respiratory infection (sARI) involves nationwide sentinel sites and assists in detecting any unusual trends associated with respiratory infections.

Notification of MERS-CoV was made compulsory for any PUI MERS-CoV to the national Crisis Preparedness and Response Centre (CPRC) on 1 November 2012. As of 9 April 2014, before the laboratory-confirmed MERS-CoV case reported here, the $\mathrm{MoH}$ received a total of 507 PUI MERS-CoV notifications and all test results for MERSCoV were negative.

In addition to the IMR and the National Public Health Laboratory, 12 of 15 government provincial hospital laboratories and one regional Public Health Laboratory have the capacity and capability to detect and confirm MERS-CoV infection. This is further supported by the availability of private and university laboratories that can provide similar services. There has been no change to the existing case detection algorithm or laboratory assays that would have increased the probability of detecting the first case.

\section{Contact tracing and control measures}

As soon as MERS-CoV infection was confirmed in the patient reported here, contact tracing was done. Close 
Close contacts of a case of Middle East respiratory syndrome coronavirus (MERS-CoV), Malaysia, March-April 2014 $(\mathrm{n}=199)$

\begin{tabular}{|c|c|c|}
\hline Type of close contact & Total $(n=199)$ & $\begin{array}{c}\text { Symptomatic and } \\
\text { tested for MERS-CoV } \\
(n=79)\end{array}$ \\
\hline Family members ${ }^{a}$ & 38 & 29 \\
\hline Healthcare workers & 56 & 11 \\
\hline Person in the same pilgrim group as the case ${ }^{b}$ & 17 & 17 \\
\hline Community members & 67 & 13 \\
\hline $\begin{array}{l}\text { Passengers on the same flight as the case occupying a seat located either within two rows in } \\
\text { the front and back, or lateral to the case in both flights taken to return to Malaysiac }\end{array}$ & 15 & 3 \\
\hline Passengers on board both flights who called CPRC ${ }^{d}$ & 6 & 6 \\
\hline
\end{tabular}

CPCR: Malaysian national Crisis Preparedness and Response Centre.

Close contacts presenting with any symptoms in a period of 14 days after their last contact with the case were tested for MERS-CoV, while close contacts who remained asymptomatic during this period were not tested.

axcluding one family member who was in the same pilgrim group as the case.

${ }^{b}$ Including nine passengers on the same flights as the case who were sitting within two rows in the front and in the back of the case, or whose seat was lateral to the case.

c These 15 passengers were not part of the same pilgrim group as the case and consisted of 12 Malaysians and three foreigners.

d Passengers on the same flights, who were from a different pilgrim group and not seated lateral to the case or within two rows back or front of the case, but who called CPRC due to symptoms.

contacts consisted of family members, community members (including friends), members from the same pilgrim group, and healthcare workers who had contact with the case. Fellow passengers sitting within two rows in the front and back or seated lateral to the case on both return flights to Malaysia were also considered close contacts. Samples were also taken from some of the symptomatic passengers who were also on board the same flights as the case and had contacted CPRC. Samples were taken as these individuals could have had contact at any time while boarding or while in transit in Istanbul.

A total of 199 close contacts were identified and placed on surveillance for 14 days starting from the last day of contact with the case. Throat swab samples were taken from 79 of them who were symptomatic. Samples were taken only once. Results from the samples taken were negative. Close contacts who were asymptomatic were given home assessment tools and those who remained asymptomatic were not tested. Among the 199 close contacts, 24 consisted of the passengers on board the same flights, who were sitting within two rows in the front, the back or lateral to the case and another six who had contacted CPRC due to symptoms. Twenty-one of these 24 passengers were from Malaysia and were contacted by the Malaysian health department.

It was quite difficult to reach the remaining three close contact passengers, who were not from Malaysia. We noticed that as not all airlines have the details of passengers, this is a limitation for contact tracing of passengers. However, $\mathrm{MoH}$ has managed to get the contact details of the three passengers and is currently in the process of contacting them. MoH also published press statements in local newspapers advising passengers of both flights to contact the CPRC. Details on the type of close contacts and number of samples taken are given in Table.

As this is the first MERS-CoV infection in Malaysia, the community measures taken in the vicinity of the patient were rather extensive. In addition to the activities carried out by the $\mathrm{MoH}$, a local member of the Parliament took the initiative to advise the community from the same village as the case to seek medical attention if they became ill with respiratory symptoms. A local service point of screening was set up and those manning the service point provided information on MERS-CoV infection to the villagers.

Strategic health communication represents a big part of our efforts to increase the public awareness and to overcome public anxiety. Official press statements were released through the office of the Minister and Director General of Health. Subsequently, there were daily engagements with the public to provide regular updates through daily press statements, the $\mathrm{MoH}$ website and social media (e.g. CPRC Facebook). The public was educated on MERS-CoV, informed on MoH's preparedness and response and provided with travel health advice through regular interviews or talk shows on local television and radio stations.

\section{Discussion and conclusion}

The relative paucity of MERS-CoV cases to date is consistent with the disease epidemiology, which over the last two years accounts for approximatively 250 cases 
in 10 countries and the majority of cases in Saudi Arabia. Cases outside the Middle East are mostly imported cases and mainly healthcare workers tending for the cases and family members, i.e. very close contacts, become secondary cases. Muslim countries specifically are at risk of importation of the virus, because a large number of visitors to Saudi Arabia come from these countries. As such, it appears inevitable that Malaysia will detect imported cases over time.That we managed to detect our first case in Asia is due to our vigilant surveillance system.

Although our case had travelled to Saudi Arabia with a group of 17 fellow pilgrims, none of them appear to have been affected by MERS-CoV. To date, it is still unclear how humans acquire MERS-CoV and what kind of exposures represent a potential risk for getting ill. As some other cases of MERS-CoV infection, the case reported here had an underlying condition [11]. Although limited human-to-human and nosocomial transmission has been reported [12], he did not have any contact with the local healthcare system during his journey in Saudi Arabia. He was nevertheless visiting the country at a time when a sharp increase in MERS-CoV cases was occurring [13]. Some studies have shown that camels on the Arabian Peninsula are frequently infected with MERS-CoV $[14,15]$ and high viral loads found in camel nasal and conjunctival swabs suggest possible zoonotic transmission by the respiratory route [16]. It has also been reported that MERS-CoV can survive in raw camel milk [17]. In light of this, the fact that the case reported here was in close contact with camels and drank unpasteurised camel milk may be of relevance, although a clear route of transmission cannot be established.

This incident has highlighted the importance of preparedness and response mechanisms for early detection and prompt activation of prevention and control measures. The areas, which we can improve are to further educate Umrah pilgrims on the need for prevention during the journey and the need to seek early treatment at goverment clinics when they fall ill upon returning home. Private clinics in Malaysia may not be as vigilant on the criteria for screening of PUI and this should be addressed. Would there be evidence for a sustained human-to-human transmission in the future and secondary cases, the MoH of Malaysia may consider a need to quarantine close contacts.

\section{Acknowledgments}

The authors would like to thank the Director General of Health Malaysia for his permission to publish this paper and the World Health Organization for all its support. The authors are grateful to local health authorities, all related Divisions in the $\mathrm{MoH}$ Malaysia and other agencies involved in responding to this incident.

\section{Conflict of interest}

None declared.
Authors' contributions

Wrote the manuscript: Premila Devi Jeganathan, Wan Noraini Wan Mohamed Noor, Norhayati Rusli, Badrul Hashim Abdul Samad, Zainah Saat. Provided comments and revised the manuscript: Chong Chee Kheong, Fadzilah Kamaludin, Hirman Ismail, Lokman Hakim Sulaiman, Noor Hisham Abdullah.

\section{References}

1. Ministry of Health Malaysia. Policies and procedures of infection control 2nd edition. Putrajaya: Ministry of Health Malaysia; 2010. Available from: http://www.moh.gov.my/ images/gallery/Polisi/infection_control.pdf

2. World Health Organization (WHO). Laboratory Testing for Middle East Respiratory Syndrome Coronavirus. Geneva: WHO; Sep 2013. Available from: http://www.who.int/csr/disease/ coronavirus_infections/MERS_Lab_recos_16_Sept_2013. pdf?ua $=1$

3. World Health Organization (WHO). Middle East Respiratory Syndrome Coronavirus (MERS-CoV). Initial Interview Questionnaire of Cases. Guide for the interviewer. Geneva: WHO. [Accessed 05 May 2014]. Available from: http://www. who.int/csr/disease/coronavirus_infections/MERS_case_ investigation_questionnaire.pdf

4. Danielsson N, on behalf of the ECDC Internal Response Team, Catchpole M. Novel coronavirus associated with severe respiratory disease: Case definition and public health measures . Euro Surveill. 2012;17(39):pii=20282.

5. Zaki AM, van Boheemen S, Bestebroer TM, Osterhaus AD, Fouchier RA. Isolation of a novel coronavirus from a man with pneumonia in Saudi Arabia. N Engl J Med. 367(19):1814-20. http://dx.doi.org/10.1056/NEJMoa1211721

6. Hijawi B, Abdallat M, Sayaydeh A, Alqasrawi S, Haddadin $\mathrm{A}$, Jaarour $\mathrm{N}$ et al. Novel coronavirus infections in Jordan, April 2012: epidemiological findings from a retrospective investigation. East Mediterr Health J. 2013; 19 Suppl 1:S12-8.

7. World Health Organization (WHO). WHO risk assessment: Middle East respiratory syndrome coronavirus (MERS-CoV). 24 April 2014. Geneva: WHO; Apr 2014. Available from: http:// www.who.int/csr/disease/coronavirus infections/MERS CoV RA_20140424.pdf?ua=1

8. World Health Organization (WHO). Revised interim case definition for reporting to WHO - Middle East respiratory Syndrome coronovirus (MERS-CoV). Interim case definitions as of 3 July 2013. Geneva: WHO. [Accessed o5 May 2014]. Available from: http://www.who.int/csr/disease/ coronavirus infections/case definition/en/

9. Ministry of Health, Malaysia. Makluman StatusTerkini Mengenai Kejadian Jangkitan MERS-CoV Dan Langkah Kesiapsiagaan Kementerian Kesihatan Malaysia (BIL. 02/2013) [Accessed 05 May 2014]. Malaysian. Available from: http:// htan.moh.gov.my/v1/htdocs/Makluman\%20Status\%20 Terkini\%20Mengenai\%20Kejadian\%20Jangkitan\%20MERSCoV\%20Bil.\%2002_2013\%20(Ogos\%202013).pdf

10. Ministry of Health Malaysia. Malaysia Influenza Surveillance System (M.I.S.S): Clinical and Laboratory Surveillance. Putrajaya: Ministry of Health Malaysia; Sep 2004, Available from: http://h1n1.moh.gov.my/NIPPP/MISS\%20-Clinical\%20 Lab\%20Surveillance.pdf

11. Assiri A, Al-Tawfiq JA, Al-Rabeeah AA, Al-Rabiah FA, Al-Hajiar S, Al-Barrak A, et al. Epidemiological, demographic, and clinical characteristics of 47 cases of Middle East respiratory syndrome coronavirus disease from Saudi Arabia: a descriptive study. Lancet Infect Dis. 2013;13(9):752-61. http://dx.doi.org/10.1016/S1473-3099(13)70204-4

12. Assiri A, McGeer A, Perl TM, Price CS, Al Rabeeah AA, Cummings DA, et al. Hospital outbreak of Middle East respiratory syndrome coronavirus. N Engl J Med. 2013;369(5):407-16 http://dx.doi.org/10.1056/NEJMoa1306742

13. European Centre for Disease Prevention and Control (ECDC). Updated rapid risk assessment. Severe respiratory disease associated with Middle East respiratory syndrome coronavirus (MERS-CoV), Ninth update, 24 April 2014. Stockholm: ECDC; Apr 2014. Available from: http://www.ecdc.europa.eu/en/ publications/Publications/Middle-East-respiratory-syndromecoronavirus-risk-assessment-25-April-2014.pdf

14. Reusken CB, Haagmans BL, Müller MA, Gutierrez C, Godeke G), Meyer B, et al. Middle East respiratory syndrome coronavirus neutralising serum antibodies in dromedary camels: a comparative serological study. Lancet Infect Dis. 
2013;13(10):859-66.

http://dx.doi.org/10.1016/S1473-3099(13)70164-6

15. Perera RA, Wang P, Gomaa MR, El-Shesheny R, Kandeil A, Bagato 0, et al. Seroepidemiology for MERS coronavirus using microneutralisation and pseudoparticle virus neutralisation assays reveal a high prevalence of antibody in dromedary camels in Egypt, June 2013. Euro Surveill.

2013;18(36): pii=20574.

http://dx.doi.org/10.2807/1560-7917.ES2013.18.36.20574

16. Nowotny N, Kolodziejek J. Middle East respiratory syndrome coronavirus (MERS-CoV) in dromedary camels, Oman, 2013. Euro Surveill. 2014;19(16): pii=20781.

http://dx.doi.org/10.2807/1560-7917.ES2014.19.16.20781

17. van Doremalen N, Bushmaker T, Karesh WB, Munster VJ.

Stability of Middle East respiratory syndrome coronavirus

in milk [letter]. Emerg Infect Dis. 2014;20(7). [Epub ahead of print].

http://dx.doi.org/10.3201/eid2007.140500 